\title{
Alloxan Dose Optimization to Induce Diabetes in Albino Mice and the Determination of the Induced Diabetes Type
}

\author{
Seham T. M.Oshkondali ${ }^{1 *}$, EL-Mahmoudy ${ }^{2}$, FadiaTaufik Samira ${ }^{1}$, A alacrouk ${ }^{1}$, Khaled Milad Abu $^{3}$, AhlamRashed ${ }^{2}$, Ali
} Elahrash Zuhur ${ }^{1}$, RajabAlmesai ${ }^{2}$

${ }^{1}$ Faculty of Medicine/ Zawia University Zawiya, Libya

${ }^{2}$ Faculty of Science/Zawia University Zawiya, Libya

${ }^{3}$ Medical Research Center/Zawia City Zawiya, Libya

DOI: 10.36348/SJMPS.2019.v05i10.001 | Received: 25.08.2019| Accepted: 11.09.2019| Published: 13.10 .2019

*Corresponding author: Seham T.M. Oshkondali

\section{Abstract}

Several chemical compounds are used worldwide to induce diabetes in animals. Alloxan monohydrate and streptozotocin are among those are commonly used because of their cheap coast. However, other chemical compounds are less toxic but more expensive. This pilot study was conducted to use alloxan as diabetes inducer, and to determine the suitable dose which can make a diabetic albino mice model. The type of induced diabetes was also differentiated by using glimepiride tablets. Three mice were injected with three doses of alloxan monohydrate intraperitoneally $(150 \mathrm{mg}-100 \mathrm{mg}-150 \mathrm{mg}) / \mathrm{kg}$ in two days intervals respectively in order to induce and maintain diabetes. The fasting blood sugar measured before and after each alloxan injection. Results showed an increasing in blood glucose levels from an average of $81 \mathrm{mg} / \mathrm{dl}$ to 168.6 $\mathrm{mg} / \mathrm{dl}$ after the first dose $(150 \mathrm{mg} / \mathrm{kg})$ of alloxan, after 2nd dose $(100 \mathrm{mg} / \mathrm{kg})$ of alloxan from $117.83 \mathrm{mg} / \mathrm{dl}$ to 154.67 $\mathrm{mg} / \mathrm{dl}$, and from $154.67 \mathrm{mg} / \mathrm{dl}$ to $173 \mathrm{mg} / \mathrm{dl}$ after $3 \mathrm{rd}$ dose $(150 \mathrm{mg} / \mathrm{kg})$. On the other hand the glimepiride which was given to mice orally caused dramatic decrease in blood sugar level from $173 \mathrm{mg} / \mathrm{dl}$ to $93.67 \mathrm{mg} / \mathrm{dl}$ after $4 \mathrm{hrs}$ of administration. From this study it was conducted that the use of different doses of alloxan can induce and maintain diabetes and the induced diabetes is type II. Further work is in progress to examine the use of plant extracts in order to regulate blood sugar levels in induced diabetic mice.

Keywords: Alloxan, diabetes streptozotocin.

Copyright @ 2019: This is an open-access article distributed under the terms of the Creative Commons Attribution license which permits unrestricted use, distribution, and reproduction in any medium for non-commercial use (NonCommercial, or CC-BY-NC) provided the original author and source are credited.

\section{INTRODUCTION}

Diabetes mellitus is a genetic inherited disease with multiple alleles located on different chromosomes. The defect is a decrease in insulin secretion or in insulin action leads to an increase in blood sugar level $[1,2]$. Millions of people affected worldwide. The chronic hyperglycemia with this disease causes the occurrence of organ lesions in kidneys, eyes, nerves and blood vessels. Controlling the glycemic state is very important to avoid this complication [3]. Type II diabetes happen due to deficiency of insulin. The body can produce insulin but gradually their cells do not take glucose from blood. This indicates that sort of insulin resistance is developed [4]. Diabetes mellitus type II is more common in the obese at age more than 40 years. State of hyperglycemia leads to much complication such as vascular insult accounts for morbidities and mortalities. Glycemic control is important to avoid these complications $[5,6]$. The experimental animal model of a disease is important to understand the disease pathophysiology and also the development of drugs used for it as treatment [7]. Various diabetic animal models have been established either surgically [8] orchemically [7] using variety of modes, doses and routes of administration [9-11). Alloxan in its monohydrate form is one of the chemical agents used for the diabetes induction since long [12, 13]. A previous study revealed that by using different doses of alloxan $100 \mathrm{mg}, 200 \mathrm{mg}, 300 \mathrm{mg}$ and $400 \mathrm{mg}$ in a single dose. Most of the mice became diabetic on first administration. The animals did not sustain the 400 $\mathrm{mg} / \mathrm{kg}$ dose and showed more than $70 \%$ mortality [14].

\section{MATERIAL AND METHOD}

This pilot study was conducted at Zawia Madical Research Center in order to optimize the Alloxan dose that induces diabetes in experimental Albino mice and to determine the type of induced diabetes.

Three male albino mice were used in this study weighed $27.25 \mathrm{gm}, 23.68 \mathrm{gm}$ and $26.85 \mathrm{gm}$.The mice 
were held back animal house and kept in stainless steel cages in optimum conditions of temperature, humidity and light and fed overnight. On second day body weight and FBS were measured by ACCUA-check device (Rache Diag. Gmbh, Germany, ser.No.4015630059362) recommended by Bromme, 2000. then, the mice injected intraperitoneally by $150 \mathrm{mg} / \mathrm{kg}$ of alloxan monohydrate solved in a phosphate buffer saline and maintained free access for food and water. After $48 \mathrm{hrs}$. Both body weight and FBS were measured. In order to ensure occurrence of diabetes, two subsequent individual doses of alloxan were given. The former dose $(100 \mathrm{mg} / \mathrm{kg})$ was given 2 days after the first dose and the later $(150 \mathrm{mg} / \mathrm{kg})$ was given 2 days after the second dose. Both body weight and F.B.S were measured before and after $48 \mathrm{hrs}$. Of injection. To determine the type of diabetes, $0.5 \mathrm{mg} / \mathrm{kg}$ body weight of amaryl was given. Then F.B.S was measured 3 times in $2 \mathrm{hrs}$ intervals between measurements.

\section{RESULTS}

Results in table (I) showed the readings of F.B.S and body weights of mice before and after injection of $1^{\text {st }}$ dose $(150 \mathrm{mg} / \mathrm{kg})$ of alloxan. As can be seen from the table, there was a dramatic increase $(168.67 \mathrm{mg} / \mathrm{dl})$ after $48 \mathrm{hrs}$. of injection and so the body weight.

Table-I: the Bwt and FBS of mice before and after injection of $150 \mathrm{mg} / \mathrm{kg}$ of alloxan

\begin{tabular}{|l|l|l|l|l|l|}
\hline No of mice & Alloxan dose & Wt before & FBS before & Wt after & FBS after \\
\hline Mice 1 & $150 \mathrm{mg} / \mathrm{kg}$ & $27.25 \mathrm{gm}$ & $78 \mathrm{mg} / \mathrm{dl}$ & $30.7 \mathrm{gm}$ & $190 \mathrm{mg} / \mathrm{dl}$ \\
\hline Mice 2 & $150 \mathrm{mg} / \mathrm{kg}$ & $23.68 \mathrm{gm}$ & $73 \mathrm{mg} / \mathrm{dl}$ & $27.61 \mathrm{gm}$ & $166 \mathrm{mg} / \mathrm{dl}$ \\
\hline Mice 3 & $150 \mathrm{mg} / \mathrm{kg}$ & $26.85 \mathrm{gm}$ & $92 \mathrm{mg} / \mathrm{dl}$ & $29.48 \mathrm{gm}$ & $150 \mathrm{mg} / \mathrm{dl}$ \\
\hline Average & & $25.93 \mathrm{gm} \pm 1.95$ & $81 \mathrm{mg} / \mathrm{dl} \pm 6.84$ & $29.26 \mathrm{gm} \pm 1.55$ & $168.67 \mathrm{mg} / \mathrm{dl} \pm 20.13$ \\
\hline
\end{tabular}

Results in table (II \& III), also showed an increase in F.B.S after the injection of $2^{\text {nd }}(100 \mathrm{mg} / \mathrm{kg})$ and $3^{\text {rd }}(150 \mathrm{mg} / \mathrm{kg})$ doses of alloxan reaching to an average of $(173 \mathrm{mg} / \mathrm{ld})$ after the $3^{\text {rd }}$ dose. On the other hand, mice body weights were increased in parallel.

Table-II: The Bwt and FBS of mice before and after injection of $100 \mathrm{mg} / \mathrm{kg}$ of alloxan

\begin{tabular}{|l|l|l|l|l|l|}
\hline No of mice & Alloxan dose & WT before & FBS before & Wt after & FBS after \\
\hline Mice 1 & $100 \mathrm{mg} / \mathrm{dl}$ & $30.7 \mathrm{gm}$ & $111 \mathrm{mg} / \mathrm{dl}$ & $32 \mathrm{gm}$ & $144 \mathrm{mg} / \mathrm{dl}$ \\
\hline Mice 2 & $100 \mathrm{mg} / \mathrm{dl}$ & $27.6 \mathrm{gm}$ & $127.5 \mathrm{mg} / \mathrm{dl}$ & $29.41 \mathrm{gm}$ & $182 \mathrm{mg} / \mathrm{dl}$ \\
\hline Mice 3 & $100 \mathrm{mg} / \mathrm{dl}$ & $29.48 \mathrm{gm}$ & $115 \mathrm{mg} / \mathrm{dl}$ & $32.36 \mathrm{gm}$ & $138 \mathrm{mg} / \mathrm{dl}$ \\
\hline Average & & $29.26 \mathrm{gm} \pm 1.56$ & $117.83 \mathrm{gm} / \mathrm{dl} \pm 8.60$ & $31.26 \mathrm{gm} \pm 1.60$ & $168.67 \mathrm{mg} / \mathrm{dl} \pm 23.86$ \\
\hline
\end{tabular}

Table-III: The Bwt and FBS of mice before and after injection of $150 \mathrm{mg} / \mathrm{kg}$ of alloxan

\begin{tabular}{|l|l|l|l|l|l|}
\hline No of mice & Alloxan dose & Wt before & FBS before & Wt after & FBS after \\
\hline Mice 1 & $150 \mathrm{mg} / \mathrm{dl}$ & $32 \mathrm{gm}$ & $144 \mathrm{mg} / \mathrm{dl}$ & $31.69 \mathrm{gm}$ & $168 \mathrm{mg} / \mathrm{dl}$ \\
\hline Mice 2 & $150 \mathrm{mg} / \mathrm{dl}$ & $29.4 \mathrm{gm}$ & $182 \mathrm{mg} / \mathrm{dl}$ & $29.84 \mathrm{gm}$ & $200 \mathrm{mg} / \mathrm{dl}$ \\
\hline Mice 3 & $150 \mathrm{mg} / \mathrm{dl}$ & $32.36 \mathrm{gm}$ & $138 \mathrm{mg} / \mathrm{dl}$ & $34.22 \mathrm{gm}$ & $151 \mathrm{mg} / \mathrm{dl}$ \\
\hline Average & & $31.25 \mathrm{gm} \pm 1.70$ & $154.67 \mathrm{mg} / \mathrm{dl} \pm 23.86$ & $31.9 \mathrm{gm} \pm 2.19$ & $173 \mathrm{mg} / \mathrm{dl} \pm 24.87$ \\
\hline
\end{tabular}

When Amaryl was used as hypoglycemic agent, results in table (IV) showed that there was a dramatic decrease in F.B.S. from an average of $(173 \mathrm{mg} / \mathrm{dl})$ to $(82.67 \mathrm{mg} / \mathrm{dl})$ after $1 \mathrm{hr}$. of administration then started to increase gradually reaching $93.67 \mathrm{mg} / \mathrm{dl}$ after $4 \mathrm{hrs}$. This observation indicating that the induced diabetes is of type II since other types do not respond to such drug.

Table-IV: the FBS before and after amaryl dose.

\begin{tabular}{|l|l|l|l|l|}
\hline No of mice & FBS before & RBS after $\mathbf{~ h r}$ & RBS after $\mathbf{~ h r}$ & RBS after 4 hr \\
\hline Mice 1 & $168 \mathrm{mg} / \mathrm{dl}$ & $84 \mathrm{mg} / \mathrm{dl}$ & $90 \mathrm{mg} / \mathrm{dl}$ & $75 \mathrm{mg} / \mathrm{dl}$ \\
\hline Mice 2 & $200 \mathrm{mg} / \mathrm{dl}$ & $81 \mathrm{mg} / \mathrm{dl}$ & $93 \mathrm{mg} / \mathrm{dl}$ & $117 \mathrm{mg} / \mathrm{dl}$ \\
\hline Mice 3 & $151 \mathrm{mg} / \mathrm{dl}$ & $83 \mathrm{mg} / \mathrm{dl}$ & $77 \mathrm{mg} / \mathrm{dl}$ & $89 \mathrm{mg} / \mathrm{dl}$ \\
\hline Average & $173 \mathrm{mg} / \mathrm{dl} \pm 24.88$ & $82.67 \mathrm{mg} / \mathrm{dl} \pm 1.53$ & $86.67 \mathrm{mg} / \mathrm{dl} \pm 8.50$ & $93.67 \mathrm{mg} / \mathrm{dl} \pm 21.38$ \\
\hline
\end{tabular}

\section{DISCUSSION}

Alloxan was used in this study to induce diabetes in albino mice as it is one of the most commonly used chemical compound for induction of diabetes mellitus in animals since long $[15,13]$.
This pilot study conducted mainly to optimize the dose of alloxan needed to induce diabetes and make a diabetic mice model and to determine the type of diabetes. As shown from the results in table (I, II \& III) the use of alloxan as a diabetogenic agent managed to induce diabetes in mice from the first dose $(150 \mathrm{mg} / \mathrm{kg})$ 
as indicated by the increase in blood sugar levels in mice from an average of $(81 \mathrm{mg} / \mathrm{dl})$ to $(168 \mathrm{mg} / \mathrm{dl})$. Although, the effect of the compound varies considerably amongst species, age and metabolic state of the animal $[12,13]$, the results were in agreement with many workers who find similar results in which a single dose could lead to make the animal diabetic. Among them, Yanarday and Colak [16] who find that injection of a single dose of $(150 \mathrm{mg} / \mathrm{kg})$ body weight of alloxan after $18 \mathrm{hrs}$ fasting induced hyperglycemia in experimental rats. Gosh and Suryawanshi [9]; Akuodor, et al. [11] were also reported that $(150 \mathrm{mg} / \mathrm{kg})$ of alloxan monohydrate induced diabetes in rats. However, other workers reported different results in which different doses were needed to induce diabetes even though a single dose was still capable of inducing hyperglycemia. Sarasa, et al. [10] reported $120 \mathrm{mg} / \mathrm{kg}$ while Bukhari [14], reported a dose of $200 \mathrm{mg} / \mathrm{kg}$ to produce experimental diabetes after 7 days in albino mice used as animal model.

Although, results from this study revealed that a single dose of alloxan produced hyperglycemia to albino mice but, subsequent doses of $100 \mathrm{mg} / \mathrm{kg}$ and $150 \mathrm{mg} / \mathrm{kg}$ were used to inject mice .This step was performed to ensure and maintain the state of hyperglycemia for an extended period of time since the model are going to be used for other experiments where plant extracts known to regulate blood sugar level are going to be tested. As can be seen from table (II \& III) results showed extra subsequent doses succeeded to maintain blood sugar levels higher where it reached an average of $(173 \mathrm{mg} / \mathrm{dl})$ after $3^{\text {rd }}$ dose of injection.

One of the aims of this study is to determine the type of diabetes induced by allowance; therefore amaryl was used as a hypoglycemic agent. The dramatic decrease in blood sugar levels as shown in table (IV) was an indication that the induced diabetes was of type (II) since other types do not respond to such drug.

Alloxan is a well- known diabetogenic agent widely used to induce Type II diabetes in animals [15]. But a simplistic argument often made against the use of alloxan to induce type II diabetes mellitus in which, alloxan administration produces beta cells damage and thus leading to type I rather than type II diabetes mellitus. Studies conducted by Etuk and Mohammed [12] showed that, there was no differential response to hypoglycaemic agents by alloxan and glucose loading hyperglycemic rats. Alloxan administration in experimental animals has been reported to produce pancreatic lesion which is proportional to the dose of the drug administered and the size of the lesion also correlates with the pancreatic insulin content [17]. This perhaps explains why the drug at a low or medium dose does not produce absolute but insufficient insulin deficiency in experimental animals. The current study revealed that by using three doses of alloxan in $48 \mathrm{hrs}$ intervals the model can be conducted and the dose indicated that the insult happened to pancreatic tissue was partial which assured by the hypoglycemic effect of amaryl on the diabetic mice models. From this pilot study it was concluded that the use of alloxan at low to medium doses of (100- $150 \mathrm{mg} / \mathrm{kg}$ ) were successful way to induce type II diabetes in albino mice and the use of subsequent doses of $150 \mathrm{mg} / \mathrm{kg}, \quad 100 \mathrm{mg} / \mathrm{kg}$ and $150 \mathrm{mg} / \mathrm{kg}$ in 2 days intervals to insure and maintain diabetic state is recommended.

\section{REFERENCES}

1. Degirmenci, I., Ustener, M.C., Kalender, Y., Kalender, S., \&Gunes, H.V. (2005). The effects of Acarbose and Rumexpatientia on ultra-structural and biochemical changes of pancreatic $\beta$-cells in streptozotocin-induced diabetic rats. J. Ethano. Pharmacol, 97(3): 555-559.

2. Kota, S.K., Mehr, L.K., Jamula, S., Kota, S.K., \& Mody, K.D. (2012). Genetics of type 2 diabetes mellitus and other specific types of diabetes; its role in treatment modalities. Diabetes Metab. Syndr, 6(1): 54-58.

3. American Diabetes Association. (2016). Diagnosis and classification of diabetes. Diabetes Care 39, S13-S22.

4. Wild, S., Roglic, C., Green, A., Sicree, R., \& King, H. (2004). Global prevalence of diabetes: Estimates for theyear 2000 and projections for 2030: Diabetes Care. 27:1047-1053.

5. Steinberger, J., \& Daniels, S.R. (2003). Obesity, insulin resistance, diabetes and cardiovascular risk in children. Circulation. 107: 1448-1453.

6. Tan, K.B.C., Shin, S.W.M., Chow, W.S., Leng, L., Bucala, R., \& Belleridge, D. J., (2006). Association between serum levels of soluble receptor for advanced glycation end products and circulating advanced glycation end products in T2D. Diabetologia, 49: 2756-2762.

7. Szkudelski, T. (2001). The mechanism of alloxan and streptozotocin action in B cells of the rat pancreas. Physiol. Res, 50: 536-546.

8. Black, H. E., Rosenblum, I. Y. \&Capen, C. C. (1980). Chemically induced (StreptozotocinAlloxan) diabetes mellitus in the dogs. Am. J. Pathol, 98: 295-306.

9. Gosh, S. \&Suryawanshi, S. A., (2001). Effects of Vincarosea extracts in treatment of alloxan diabetes in albino rats. Indian J. Exp. Biol, 39: 748-759.

10. Sarasa, D., Sridhar, S., \& Prabakaran, E. (2012). Effect of an antidiabetic extract of Trigonellafoenum-Graecum on normal and alloxan induced diabetic mice. Int. J. Pharm. Sci, 4(1): 92.

11. Akuodor, G.C., Udia, P. M., Bassay, A., Chilaka, K.C. \& Okezie, O.A. (2014). Of aqueous root extract of Icacina senegalensisin alloxan induced diabetic rats. J. Acute disease, 99-103. 
12. Etuk, E.U. (2010). Animals models for studying diabetes mellitus. Agric. Biol. J. N. Am. 1: 130.

13. Iranloye, B.O., Arikawe, A.P., Rotimi, G., \& Sogbade, A.O. (2011). Anti-diabetic and antioxidant effects of Zingiberofficinale on alloxan-induced and insulin-resistant diabetic male rats. Niger. J. Physiol. Sci, 26: 89-96.

14. Bukhari, S., Abbasi, M., Ahmed, M. (2015). Dose optimization of alloxan for diabetes in albino mice. Biology, 61(2), 301-305.
15. Viana, G.S., Medeiros, A.C., Lacerda, A.M., Leal L.K, ValeT.G., Matos, F.J. (2004). Hypoglycemic and anti-lipemiceffects of the aqueous extract from Cissussicyoides.BMC Pharmacol, 8: 4-9.

16. Yanarday, R., Colac, H. (1998). Effect chard (Beta vulgaris L.varcicla) on blood glucose level in normal and alloxaninduceddiabetic rabbit. $J$. Ethnopham, 4:309-311.

17. McNeill, J.H. (1990). Experimental models of diabetes.Informa health care, 8 . 